\title{
Who did the work? Experimental philosophers and public demonstrators in Augustan England
}

\author{
STEPHEN PUMFREY*
}

The growth of modern science has been accompanied by the growth of professionalization. We can unquestionably speak of professional science since the nineteenth century, although historians dispute about where, when and how much. It is much more problematic and anachronistic to do so of the late seventeenth century, despite the familiar view that the period saw the origin of modern experimental science. This paper explores the broad implications of that problem.

One area of scientific activity, public science lecturing and demonstrating, certainly produced its first professionals in the period 1660-1730. This was a period which Geoffrey Holmes called 'Augustan England', and which he found to be marked by the expansion of many of the professions. ${ }^{1}$ Swollen lower ranks of physicians, civil servants and teachers crowded onto the ladder up to gentility, and even solicitors achieved respectability. Alongside these established types the professional scientist, such as the public lecturer, was a novelty. Later, in the high Georgian era, a small army of men like Stephen Demainbray and Benjamin Martin made recognized if precarious livings from public experimentation, but the first generation pioneers were entering new and risky territory. As Larry Stewart has shown, 'the rise of public science' was a successful social and economic transformation of the highest significance in the history of science which was part of what has been called England's commercial revolution. ${ }^{2}$

We are accustomed to think of early, pioneering professionals like Robert Hooke, Francis Hauksbee or Denis Papin as 'notable scientists'. That is how the Dictionary of Scientific Biography describes Papin, and his entry is appropriately full and fulsome. ${ }^{3}$ It is the aim of this paper to show that such judgements made no sense in Augustan society. Its professional experimenters knew more keenly than most the difficulties and obstacles which accompanied the 'making of middle class' and the concomitant reconfiguration of all English social relations. An attention to their difficulties, I think, casts important light upon the establishment of experimental learning, and continues the historiographical process of turning experiment from a triumphant given into a problem amenable to

* Department of History, University of Lancaster, Lancaster LA1 4YG.

This paper was first presented at a joint meeting of the Science Museum and the British Society for the History of Science, 'Science Lecturing in the Eighteenth Century'.

1 G. Holmes, Augustan England: Professions, State and Society, 1680-1730, London, 1982.

2 Larry Stewart, The Rise of Public Science. Rhetoric, Technology and Natural Philosophy in Newtonian Britain, 1660-1750, Cambridge, 1992.

3 DSB, s.v. 'Hauksbee, Francis'. 
genuinely historical explanation. The problem is constituted from two obstacles which acted to prevent the work of professional experimenters from receiving intellectual recognition.

In the first place, the early professional science lecturers and demonstrators were, by definition, employed to perform the service of experimenting. They generally performed for and before men of high rank who, because of their financial independence and leisured lives, were unquestionably gentlemen of property, virtue and political and cultural influence. Paid employment betokened a much lower status, and professional experimenters were very dependent upon collective or individual patronage. It is true that eighteenthcentury Enlightenment critics of the old order were beginning to argue, with gradual success, that a man's $[s i c]$ social status should be a reflection of his rational accomplishments rather than his inherited wealth and privilege. Indeed radical Whigs such as Addison and Steele promoted this new ideology just as public science was emerging, which they also promoted. Nevertheless, the liberal implications of that ideology were hotly contested, even by moderate Whigs, and few acted in accordance with it. The notion of a professional scientist was in the slow process of acquiring the status which it has today, but it still had so little that the phrase is an anachronism. Consequently, it was not clear that a paid experimenter could be a noble philosopher.

Secondly, there was the nature of the service provided. Experimental philosophy involved not only head work but also hand work. The construction and use of air-pumps, for example, demanded the manual skill and dirty, sweaty labour traditionally described as 'mechanick'. Although science lecturers might appear to differ little from minor lawyers or architects in offering professional expertise in return for a fee, the latter professions had comfortably entered the ranks of the 'pseudo-gentry' by 1700 because even though the source of their income was not property, it kept their hands clean. The better sort of artisan, such as an instrument maker, might have left 'the mechanick part of mankind'4 to be redescribed as one of the 'middling sort', but he was not genteel. In Augustan society, then, not only the conditions but also the nature of his work was suspect. Thus, where we would assume that a claimant of some discovery had performed the experiments, and had been paid to do so, Augustan social conventions would have made this doubly surprising. Those conventions fractured what for us is the unitary activity of the (professional) scientist, because they represented a different set of triangular relationships between labour, reason and social status.

This paper presents and interprets evidence that public experimental work emerged in a hierarchical society in which a person's 'reason' (qua the capacity to be accorded intellectual credibility) was strongly correlated with a social status which took little account of intellectual merit. Since social status was negatively correlated with labour (specifically paid experimental labour), the triangle put into question whether an employed experimenter or science lecturer could also be an experimental philosopher. There was a tension between the epistemological status of his productions, which looked more like experimental philosophy than mechanical labour, and the social status of his position,

4 For a discussion see Peter Earle, The Making of the English Middle Class: Business, Society and Family Life in London, 1660-1730, London, 1989, 3. 
which looked more like that of a mechanic servant than an experimental philosopher. It is worth noting, given that early modern discourses of status and rationality remained very patriarchal, that a woman science lecturer (had one existed) would have introduced further fractures and tensions. ${ }^{5}$

'Who did the work ?' thus becomes a pertinent question to ask of Augustan experimental science. It links to profound issues which concerned the upper orders and which came to divide Whigs and Tories in the 'first age of party'. Was rapid change within the social hierarchy to be resisted or embraced? What legitimate grounds divided an élite from the people? Who, amongst the emerging middle orders, should have a political voice, and who should be admitted to the republic of letters? Was commercialization, most visibly of agriculture, which brought increased enclosure and wage labouring, benefiting the nation? Or was 'the monied interest' destroying a traditional, harmonious social order based on patronage and deference? Were tradesmen now 'quality', and how should a proper gentleman behave towards them?

By the early eighteenth century rapid change had produced many ideologists trying to make sense of the new circumstances. The Tory Henry St John complained, on behalf of 'the landed men', that 'a new interest has been created... [whose] men are become their masters, who formerly would with joy have been their servants'. Conversely Daniel Defoe insisted that trade was 'the staff on which both king and people lean, and which (if it should sink) the whole fabric must fall' ${ }^{6}$ Yet all but the most radical Whigs continued to insist upon the proper observance of place despite (or because of) increased social mobility. Defoe was typical when he refused to endow political rights 'upon the inhabitants, but upon the Freeholders, the Freeholders are the proper owners of the Country'. And while Tories were shocked even by such a limited commonwealth, they could agree with the Whig and Boyle Lecturer Samuel Clarke's insistence that order depended upon a man not 'being either uneasy or discontented, that others are placed by providence in different and superior stations of the world; or so extremely and unreasonably solicitous to change his state for the future, as thereby to neglect his present duty'. ${ }^{7}$ Faced with a society and its presiding ideologies in transition, many Augustans acted, wrote and thought contradictorily, in ways which extended to their assessment of experimental work.

The contradictions are very apparent in the political theory of John Locke, the self-styled 'underlabourer' to Boyle, Sydenham and 'the incomparable Mr. Newton', Fellow of the Royal Society, advocate of commerce and foremost Whig ideologist of the 'Glorious Revolution'. In his Second Treatise on Government Locke essayed a solution to the problem of how to justify the overthrow of an established hierarchy (which most Tories supported, however reluctantly) whilst safeguarding, against Whigs and orhers who sought more radical change, the effective rule of an élite - albeit a more enterprising one. Since Locke based his political theory on concepts of the individual's inalienable liberty, and

5 For a recent discussion of women and early modern science, see Patricia Phillips, The Scientific Lady: A Social History of Women's Scientific Interests, 1520-1918, London, 1990. I am grateful for the editor's reminder that gender compounded the fractures.

6 See H. T. Dickinson, Liberty and Property. Political ldeology in Eighteenth-Century Britain, London, 1977, $52,86$.

7 Dickinson, op. cit. (6), 88-9, 87-8. 
rights to property and citizenship through his labour, Locke's problem had a specific form: how to prevent rights being claimed by the entire middle class, indeed by all labouring men. ${ }^{8}$

Locke's chief target was Robert Filmer's classical defence of the old order, Patriarcha, first published in 1653. Filmer's ideology had gained renewed popularity among Tories during the political crises of the 1670s and 1680s. As R. Tully explains, a central 'classical belief' was 'that labour and property are incompatible. Those who labour can own no property and those who own property do not labour.' A related belief was that 'the master owns the labour and the products of his servants' ${ }^{9}$ Against this, Locke asserted supposed natural laws and rights, which reflected the interests of entrepreneurs and actively improving landowners: ' $[E]$ very man has a Property in his own Person. This no Body has any Right to but himself. The Labour of his Body, and the Work of his Hands, we may say, are properly his. ${ }^{10}$ Superficially liberal, even socialist judgements of the modernity of his conception of property ${ }^{11}$ have produced, for generations of commentators, the paradox of Locke's ensuing passage: 'Thus the Grass my Horse has bit; the Turfs my Servant has cut; and the Ore I have digg' $d$ in any place where I have a right to them in common with others, becomes my Property. ${ }^{12}$

Locke appears to have held both the 'modern' view that labour created absolute property rights and the classical view that 'the Turfs my Servant has cut ... become my Property'. Although recent commentators such as MacPherson, Tully, Tribe and Wood differ in their resolutions of the paradox, they agree that Locke was engaged in the far from modern task of justifying new and rapidly evolving socio-economic relations. ${ }^{13}$ Their resolutions rightly focus upon reading Locke in the context of élite Augustan beliefs and practices concerning labour, property and master-servant relations. Such readings are of great importance in the resolution of the more specific paradoxical relations between gentlemen philosophers, such as Fellows of the Royal Society, and their experimental servants.

For leisured Fellows at meetings of the early Royal Society, these profound questions took two circumscribed forms. First, was experimental work appropriate to their 'superior

8 As Dickinson, op. cit. (6), 57, notes, 'only a minority of [Whigs] were committed to principles which might be regarded as genuinely liberal... It is essential to remember that the Whigs shared many of the prejudices, assumptions and ultimate objectives of their Tory opponents.' Concerning Locke he comments that 'there is no reason to doubt that he accepted the dependance of the majority of the population on the aristocracy, gentry and clergy. Other Whig theorists were more explicit than Locke and they certainly restricted active political rights to men of property' (p. 69). Despite the literally Whiggish readings of past political historians, Locke can no longer be seen as a far-sighted advocate of modern, liberal democracy any more than the Royal Society should be seen as a proto-research institute.

9 R. Tully, A Discourse on Property. John Locke and his Adversaries, Cambridge, 1980, 135.

10 John Locke, Two Treatises of Government. A Critical Edition with an Introduction and apparatus criticus by Peter Laslett, Cambridge, 1964, 305-6. This is Locke's section 27 (hereafter ' $\$ 27$ ').

11 For a Marxist reading see D. G. Ritchie, 'Locke's theory of property', in his Darwin and Hegel, London, 1893.

12 Locke, op. cit. (10), 307 (\$28).

13 Tully op. cit. (9) ; C. B. Macpherson, The Political Theory of Possessive Individualism: Hobbes to Locke, Oxford, 1962; Keith Tribe, Land, Labour and Economic Discourse, London, 1978; and Neal Wood, John Locke and Agrarian Capitalism, Oxford, 1984, especially chapters 4 and 5. 
station', particularly when it was remunerated? The second concerned the public experimenter/science lecturer/instrument maker whose performances were paid for from their subscriptions: was he a natural philosopher like them, an employed mechanic, or some new, in-between creation of a commercializing society? In short, how was experimental work appropriate to his station?

Such questions have recently received attention from Steven Shapin and myself. ${ }^{14}$ In an earlier paper, I explored how these tensions operated upon Robert Hooke, the Royal Society's Curator of Experiments, between the 1660s and 1680s. A major factor in Hooke's difficulties was the very embryonic size, in both social span and absolute numbers, of the career ladder for the 'professional scientist' in Restoration England. Extending the study into the eighteenth-century era of science lecturers such as J. T. Desaguliers, we encounter a public sphere of commercial opportunities which Hooke would have envied, particularly those outside the Royal Society's direct influence. The Society's classical vision of the gentleman virtuoso philosopher was infiltrated by the values of trade, the market place and the 'monied interest' - values which Tories deplored and Whigs struggled with, but which created the community of commercial science and released the tensions between the roles of paid experimenter and experimental philosopher. The science lecturer, who came to bridge the gulf between experimental philosophy as work and as leisure or duty, is thus one of the more extraordinary and paradoxical products of the period.

\section{PAID EXPERIMENTERS AND THEIR HISTORICAL PARADOXES}

The rise of the paid professional was rapid. No-one in England made a living from public experimental science before Hooke became the Royal Society's 'Setled Curator of Experiments' in 1664. His differed from the traditional or private roles fulfilled by an academic lecturer like Seth Ward, a court philosopher like John Dee, a client like Thomas Hobbes or a private 'operator' like Richard Shortgrave. It was Curator Hooke's misfortune that the seventeenth century offered few other, and certainly no more prestigious or remunerative outlets for his experimental talents. ${ }^{15}$ Yet by 1734 Desaguliers could not 'help boasting of 11 or 12 Persons, who perform, Experimental courses at this time in England and other parts of the world [because] I have had the honour of having eight of them as my scholars ${ }^{16}{ }^{16}$ In seventy years a community had developed which was transforming the experimental study of nature from a gentlemanly pursuit into a publicly exchanged commodity.

The paradoxes which defeated Locke and his fellow Augustans have also misled historians of science. For one thing, we have evaluated Hooke as a leading experimental philosopher where the Royal Society treated him as a servant. ${ }^{17}$ Secondly, commentators

14 S. Shapin, 'Who was Robert Hooke?', in Robert Hooke: New Studies (ed. M. Hunter and S. Schaffer), Woodbridge, Suffolk, 1989, 257-83 and S. Pumfrey, 'Ideas above his station: a social study of Hooke's curatorship of experiments', History of Science (1991), 29, 1-44. Shapin's A Social History of Truth: Gentility, Credibility and Scientific Knowledge in Seventeenth Century England, Chicago, 1994, is a broader study which was published too recently for consideration in this paper.

15 Hooke's disastrous period as Secretary to the Society showed that this was not a viable promotion.

16 J. T. Desaguliers, A Course of Experimental Philosophy, volume I, London, 1734, p. $\mathrm{c}^{\mathrm{v}}$.

17 Pumfrey, op. cit. (14), and Shapin, 'Hooke', op. cit. (14). 
have wondered why the Society's most effective experimenters consistently came from the 'wrong class'. These men, like the lecturing community they frequently belonged to, were not gentlemen. As John Heilbron observed, 'Stephen Gray, a dyer by trade, fell below the social level at which the Society aimed. ${ }^{18}$ Thirdly, why did some of the major experimentalists of this period die in poverty and obscurity, with only historians to restore their credit? Where the DSB commemorates Denis Papin as a 'notable scientist', the Royal Society deliberately cold-shouldered the destitute Huguenot as he made his last appeals for recompense and employment. ${ }^{19}$ Fourthly, why were the Fellows of the Society most famous for their experimental discoveries, like Hooke, Papin and Gray, far from being fêted by colleagues, frequently in dispute with them about the intellectual property rights to their work.

Lastly, historians have found it disappointingly inconsistent that, despite the powerful and persistent experimentalist rhetoric generated within the Society first by an 'active nucleus' of founding Fellows and then by Newton and his allies, the early Society's experimental programme was never securely established. While it may have been a 'golden age' for the reputation of individual Fellows and of the Philosophical Transactions, meetings after 1666 left much to be desired. Thanks to the successive revisions of Espinasse, Hoppen and Hunter, we no longer think of the Society as the first research institute, with Hooke as a research director. But its fragile support for experimental practice has only recently been fully documented. Marie Boas Hall observes that

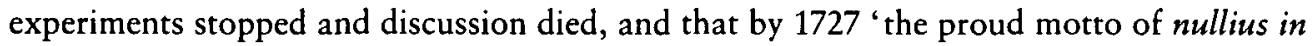
verba had little or no force when the Fellows no longer wished to see for themselves', ${ }^{20}$ Every member was constantly exhorted, indeed bribed to remedy an ever-present dearth. Yet from 1668, when a 20 shilling medal was available to any experimenter other than Curator Hooke, through numerous reforms later in the century, and still unmoved by the $£ 5$ reward generated by Copley's bequest of 1709 , the Fellows sat on their soft hands. One of Newton's final anxieties was the dishonour (blamed on Desaguliers) of Copley's name. ${ }^{21}$

All of these paradoxes are graphically illustrated by contrasting attitudes towards one of the Society's most active experimenters, and one of England's first science lecturers, Francis Hauksbee senior (c.1666-1713). The importance of Hauksbee's work with Newton on phosphorescence, electricity and optics to the enlargement of Newtonian

$18 \mathrm{~J}$. Heilbron, Physics at the Royal Society during Newton's Presidency, Los Angeles, 1984, 51.

19 For the rejection of Papin's appeals see below.

20 Marie Boas Hall, Promoting Experimental Learning. Experiment and the Royal Society, Cambridge, 1991, 132; for interpretation of the motto see C. Sutton, "Nullius in verba" and "nihil in verbis": public understanding of the role of language in science', BJHS (1994), 27, 55-64. On decline, see M. Espinasse, 'The decline and fall of Restoration science', in Past and Present (1958), 14, 71-89; K. Theodore Hoppen, 'The nature of the early Royal Society', BJHS (1976), 9, 1-24, 243-73; Michael Hunter, Establishing the New Science. The Experience of the Early Royal Society, Woodbridge, Suffolk, 1989.

21 Thomas Birch, The History of the Royal Society of London for the Improving of Natural Knowledge, From its First Rise, 4 vols., London, 1756-57, ii, 265; J. Heilbron, Physics at the Royal Society during Newton's Presidency, Los Angeles, 1984, 6-15. Following Sir Godfrey Copley's bequest, the Council decided to 'forever cause one experiment or more to be made before them... soon after the Anniversary meeting'. See the Royal Society of London Journal Book for 20 June 1717, p. 239 (hereafter entries are cited in the form JB, 20/6/17, 239). Desaguliers was the first recipient in 1718. See The Council Minutes of the Royal Society for 3 July 1717, p. 243 (hereafter entries are cited in the form CM, 3/7/17, 243.) See also CM, 5/12/17, 208-11; CM, 17/11/26, 299. 
physics in general, and to the revisions of Principia and Opticks in particular, is now established. Yet Richard Westfall concluded that 'Newton appears to have treated him not as an intellectual peer, but as a servant. ${ }^{22}$ Hauksbee was not, of course Newton's intellectual peer but the German traveller Zaccharius von Uffenbach wanted in 1710 to visit 'the natural-philosopher Hauksbee', ${ }^{23}$ not an operator. Outsiders like him would have been surprised to hear, as Council minutes typically recorded, that ' $\mathrm{Mr}$ Hauksbee was ordered forty pounds for his last years waiting upon the Society and shewing and trying their experiments. ${ }^{24}$ Even Fellows were slow to learn of his death in 1713 because the Society did not mourn his passing. Instead, Council discussed outstanding payments for his services, and:

Mrs Hawksbee was ordered twenty pounds for the service of her late husband for the time he made experiments before the Society before his death she giving a receipt in full. Mr Hawksbee his nephew was ordered five guineas for his services since his unkles [sic] death he giving a receipt in full. ${ }^{25}$

The official minutes doubtless accentuate Hauksbee's subordinate position, but the sum of the evidence consistently points, as it does for Hooke, to a man considered first and foremost to be under direction, and lacking the independence that Augustans presumed of their natural philosophers. If we too presume that he was a natural philosopher (perhaps precisely because he 'did the work') we miss the important discrepancy between the Society's assessment, and that of foreigners like von Uffenbach. The latter knew a textual, virtuous Hauksbee read out of experimental records in the Philosophical Transactions and in his Physico-Mechanical Experiments of 1709, and not a working, employed Hauksbee developing experiments for the Royal Society and other paying publics. ${ }^{26}$

The point is vivid in Nicolas Desmarest's éloge of 1754, where Hauksbee is made to embody the finest qualities of the natural philosopher. It was written as part of d'Alembert and Bremond's campaign at the Académie des Sciences to defeat the Cartesian Impulsionnaires and their esprit de système and to advance the Newtonian Attractionnaires and the esprit systèmatique. ${ }^{2 ?}$

M. Hauksbee became known around 1704 as a natural philosopher with enormous skill in manual operations, and a scrupulous precision when discussing phenomena. He can be considered as the first person in London who laid the phenomena of natural philosophy before the gaze of a sober

22 Richard S. Westfall, Never at Rest. A Biography of Isaac Newton, Cambridge, 1980, 634. See also Henry Guerlac, 'Francis Hauksbee: expérimentateur au profit de Newton', Archives internationales d'histoire des sciences (1963), 16, 113-28.

23 Westfall, op. cit. (22), 634 .

$24 \mathrm{CM}, 2 / 7 / 07,144$.

$25 \mathrm{CM}, 24 / 8 / 13,212$.

26 His accounts 'having already been read and approv'd before the Society' were collected as F. Hauksbee, Physico-Mechanical Experiments on Various Subjects. Containing an Account of Several Surprizing Phenomena Touching Light and Electricity, Producible on the Attrition of Bodies, with many other Remarkable Appearances, not before Observ'd, London, 1709. A second edition of 1719 contains subsequent experimental accounts 'not ranged by [Hauksbee] before his Death', and so printed in the order of their presentation before the Society.

27 Nicolas Desmarest, 'Discours historique et raisonné sur l'expériences de M. Hauskbée', a preface to F. Hauksbee, Expériences physico-mechaniques sur differens sujets, traduit par M. de Brémond de l'Académie Royale des Sciences, 2 vols., Paris, 1754. 
and competent nation. In his experiments we discover the first steps towards a systematic spirit... And that illustrious company [the Royal Society], convinced by the rightness of his judgements and by his skill, entrusted him with the repetition on numerous important occasions of complex experiments in order to remove doubts and to remedy uncertainties. He justified their choice... and they admired his exact observations and the finesse of his touch as much as his insight and his wisdom - the qualities which together make up the natural philosopher.$^{28}$

Desmarest also considered that, despite the dependance of English savants on Hauksbee's apparatus, 'he did not abuse this trust by turning these machines into commercial objects, which would have been to cede control to the ignorant'. That, like much else was wishful thinking. Whilst it was true that Hauksbee became known to London's natural philosophical community around 1704 , he did so as Newton's choice of casual operator for the Society and not as a natural philosopher.$^{29}$ Desmarest appears to have gleaned his fact from the preface to Desaguliers' Course in Experimental Philosophy. Desaguliers' book itself offers yet another assessment,

Dr John Keill was the first who publickly taught Natural Philosophy by Experiments in a Mathematicall Manner... in Oxford, about the year 1704 or 1705 ... There were indeed, about the same time, Experiments shewn at London by the late Mr. Hauksbee... But as they were only shewn and explained as so many curious phenomena, and not made use of as mediums to prove a series of philosophical propositions... [t] hey were Courses of Experiments, and his [Keill's] a Course of Experimental Philosophy. ${ }^{30}$

An advocate and beneficiary of commercial science, Desaguliers did not invoke Hauksbee's laborious status as he denied the rational, natural philosophical quality of his rival's experiments. Whether or not we agree with Desaguliers, the issue of historical interest is to explain the more generous judgements of von Uffenbach and Desmarest, and the decidedly less generous behaviour of the Royal Society. ${ }^{31}$ Until recently, Desmarest's image of the progressive, experimental natural philosopher has prevailed. Henri Guerlac, in his 1974 biography, found Desmarest's assessment 'valuable' ${ }^{32}$ But how is today's historian to explain the importance of pioneering professional experimenters and lecturers like Hauksbee as they set about their work for the Society? As public experimental science was forged in front of it, did the Society treat them as true philosophers, plain experimenters, mere servants, or some paradoxical mélange of all three? The answer depends first upon discovering who did the work, and then upon locating that work more precisely within Augustan ideologies.

28 Desmarest, op. cit. (27), i, pp. xl-xliii.

29 The first known contact between Hauksbee and either Newton or the Royal Society was his performance with his improved air-pump at the first meeting over which Newton presided, on 15 December 1703. He was ordered 5 guineas in July 1704. He then proposed, but was denied, more regular payment, and was told that 'he would be gratified according to the proportion of his services'. See JB, 15/12/04, 55, and CM, 12/7/04, 126.

30 Desaguliers, op. cit. (16), Preface, p. $c^{r}$. Volume $l l$ appeared in London, 1744. According to Henry Guerlac in DSB, s.v. 'Hauksbee, Francis', Hauksbee did not himself lecture until 1710. He engaged the mathematician James Hodgson to lecture for him in 1704.

31 For Hauksbee junior's involvement with the Society see below. For Desaguliers' relations with the divided Hauksbee family see Stewart, op. cit. (2), 120.

32 DSB, s.v. 'Hauksbee, Francis [1666-1713]'. For an earlier but more extensive discussion see Guerlac, op. cit. (22). 


\section{WHO DID THE WORK?}

Which men, and what kind of men, carried out experiments at the early Society? While this only requires a trawl through the minutes of meetings, methodological caution and explication are required. First, I have begun my analysis with the reconvening of the Society in 1666, when the early, enthusiastic contributions of many individual virtuosi permanently dried up, leaving the work to a few dedicated men. ${ }^{33}$ Secondly, I am concerned only with experimenters who made more than one or two isolated contributions. The first to be excluded by this yardstick is a president, Sir Isaac Newton, who made only four public performances in eleven years, three in the first year of his presidency. ${ }^{34}$ This represents superhuman dedication for a Fellow of independent means.

It is true that these criteria exclude what little virtuoso activity there was between 1660 and 1730, bur that does not render the argument circular. As my earlier study emphasized, gentlemen Fellows could perform experiments, did so frequently before 1665 , and probably continued to do so privately. When the Society invented the term 'curator of experiments' it had in mind anyone who 'took care of' an investigation. But public science was being invented in its meetings and it evolved rapidly. My earlier study was limited to Hooke's paid or 'Setled Curatorship' and could not determine whether it was Hooke's office or his personal dynamism which caused other Fellows idly to leave the experimental work to him. The timescale and personnel included in the current paper suggest that more sociostructural causes were indeed at work. That Fellows could, in principle, experiment in public, but chose to leave it to hired hands, would seem to justify excluding their one-off efforts as insignificant. In this section I wish only to establish that the work which gained the early Society its continuing reputation was generated by men whom the Society's Fellows did not value as experimental philosophers.

Of more importance and difficulty is the question of what to count as an experiment. This paper is concerned with those practices involving the physical and practical activities which are a routine part of modern experiment. Unfortunately, early modern usage of 'experiment' did not always connote them. Indeed the terminology used in the Society's minute does not map consistently onto modern categories. Not all experiments were described as such, as when ' $\mathrm{Mr}$ Hauksbee shewed a new invented air-pump and in it, upon the mercury descending, a Light'. Experiments, instruments and even curiosities from gentlemen's cabinets were equally 'shewn'.$^{35}$ By comparison with the seventeenth-century minutes, those taken during Newton's reign employ a more consistently modern notion of 'experiment'. ${ }^{36}$

Since our focus is 'work', rather than 'experiment as an actor's category', we are forced to select, and selection risks privileging those performances conforming to modern

33 Pumfrey, op. cit. (14), 4-7.

34 See JB, 17/5/04, 75; JB, 31/5/04, 76; and JB, 21/6/04, 79. These were on burning glasses. See also JB, $19 / 5 / 08,187$, on colours.

35 See JB, 15/12/03, 55. Compare the showing of a large cock's leg, a horse's stone and 'the pizzle of a possum ' in JB, 12/1/03-4, 57, and that of Hauksbee's water gauge in JB, 15/3/04, 67.

36 Linguistic criteria bring their own illumination to the history of early modern experiment. See C. Schmitt, 'Experience and experiment: a comparison of Zabarella's view with Galileo's in De motu', Studies in the Renaissance (1969), 16, 80-138. 
experimental practice. Marie Boas Hall's Promoting Experimental Learning: Experiment and the Royal Society, ${ }^{37}$ whilst extremely useful in many ways, has been charged with using the criteria for an experiment too unreflectively in this regard. She excludes, for example, trials of apparatus and demonstrations of instruments. ${ }^{38}$ The anatomical and natural historical work is particularly hard to classify, because it ranged from systematic dissections to simple exhibitions of an unusual phenomenon like a possum's penis. Virtuosi continued frequently to exhibit, 'experimentally', items from their cabinets of curiosities, but I have only counted performances which require some form of technical, practical or manual activity ${ }^{39}$ Such selection is not petitio principii, but a necessary filter for catching those who were prepared to roll up their sleeves and dirty their hands for the Society's declared cause of the promotion of natural knowledge.

Following these criteria, it emerges that the overwhelming burden of the Society's work in the six decades after 1666 devolved upon the twelve men listed below. To them must be added Nehemia Grew, who was primarily active as a curator of plants from 1672 to 1679 , and James Douglas, whose work as a curator of anatomy around 1706-07 briefly and ineffectually filled the Society's rarely met need for this kind of experiment. Although a difference between my criteria and those of Boas Hall has been admitted, it is instructive to compare her charts of experimental activity with the active periods of the men emerging on my list. What Boas Hall found to be a very uneven scatter of narrow peaks of industry, separated by expanses of dismal inactivity, resolves into a sequence of active periods of the same twelve individuals. ${ }^{40}$

Thus the Society's fortune was contingent almost from the beginning upon finding individual men willing to do its work. That there was little contingency in the class of men whom it considered suitable emerges from a comparison of the individuals' curricula vitae.

\section{THE TWELVE CHIEF EXPERIMENTERS}

Robert Hooke (1632-1701) came from a very poor clerical family. ${ }^{41}$ His Westminster and Oxford education depended upon scholarships. While in Oxford he became an 'operator' for Robert Boyle, and his mechanical skills were critical for the design of 'Boyle's' airpump. In 1662 Boyle obtained a similar position for Hooke with the Royal Society and gained 'the thanks of the society for dispensing with him for their use'. He impressed

37 Boas Hall, op. cit. (20). I have relied upon her analysis for the very slack period, from the point of view of experiment, between 1688 and 1702 .

38 Boas Hall, op. cit. (20), 4-5, where she is refreshingly open about her criteria. My reservations have been shared by other reviewers, such as Peter Dear in Isis (1993), 84, 148-9.

39 The work of the anatomy 'curator' James Douglas (see below) is a case in point. Douglas 'showed' both dissections and monstrosities, such as the skull of a mouthless puppy. See JB, 29/10/07, 164. I have not counted the latter as experimental work.

40 Westfall, op. cit. (22), 634. See below for Richard Lower and Edward Tyson. For graphs of activity from 1660 to 1727, see Boas Hall, op. cit. (20). Each chronological chapter is accompanied by one. The following list of individuals is arranged chronologically according to periods of activity in the Society.

41 For Hooke's biography, see M. Espinasse, Robert Hooke, London, 1956. For more recent assessments see Hunter and Schaffer op. cit. (14), and Pumfrey, op. cit. (14). 
enough to be made a paid curator and, later, a Fellow. He achieved international recognition through Micrographia, a publication of his microscopical observations originally prepared by the Society for presentation to Charles II. His relationship with the fellowship was later marred by his pursuit of other employments, such as surveying and lecturing, and the concomitant, acrimonious disputes about whether he had fulfilled the conditions of his stipend. In 1679 he successfully advanced Denis Papin as the Society's regular, paid experimenter. Hooke now lacked power but was rich enough not to depend upon his $£ 50$ p.a. stipend. He continued to contribute occasional discourses, and a final experiment in 1696, one of the two performed during that year. ${ }^{42}$

Richard Lower (1631-91) was an Oxford-trained physician and physiologist. Hoping that he could rectify the Society's dearth of anatomical experiments, Boyle and Hooke promoted him as a paid curator of anatomy, believing him to be a 'fit' person with 'inclinations to such an employment'. A Hooke-like burst of activity resulted in offers of a Fellowship, which he accepted, and a curatorship, which he declined 'on account of some business, in which he was at present engaged'. The Society did not renew the offer, perhaps because the statutes demanded exclusive employment of their curators. Lower rapidly became an inactive and unsuitable Fellow, and achieved the rare distinction of being expelled in $1675 .^{43}$

Frederick Slare (1648-1727) and Edward Tyson (1650-1708) are my list's odd men out. They were already well-established gentleman Fellows when they were appointed to curate experiments in 1682, with Tyson reviving the curatorship of anatomy. Their posts resulted from a major shake-up in the Society's organization, specifically designed to revive the experimental focus of meetings following Hooke's consistent failure to fulfil his promises. Indeed Slare was implicated in Hooke's sacking as Secretary and his subsequent marginalization. Slare and Tyson temporarily rectified Hooke's dereliction of duty with programmes of experiments in 1682-83, before slipping back into the typical spectatorial roles. ${ }^{44}$ The minutes make clear that they were remunerated for expenses and loss of leisure, an arrangement which the founders considered appropriate to gentlemen curators. Unlike Hooke they were not paid for labour or services.

Denis Papin (1647-c. 1712) was a Huguenot Hooke who met a tragic end. Possessed of a medical degree but of 'always inadequate finances', Papin scoured Europe for scientific employment and patrons. He began by playing Hooke to Huygens' Boyle in work on the air-pump at the Académie des Sciences, and moved on to serve Boyle himself. Having developed his 'steam digester' he was introduced to the Society by Boyle and Hooke in May 1679. Although he was paid as a clerk, his service consisted primarily of triumphant experiments, which were published by the Society as The Digester in 1680, and which brought him a Fellowship. When a better position could not be formalized he left, using his new fame to direct experiments at the Venetian academy of Giovanni Ambrosio Sarotti, whom he probably had met at the Society's meetings. He returned to the Society between 1684 and 1687 as a 'temporary curator' at $£ 30$ p.a. Again the Society could not pay him

42 Boas Hall, op. cit. (20), 94.

43 Pumfrey, op. cit. (14), 39 n23.

44 Pumfrey, op. cit. (14), 8-10, 32-5. 
enough ${ }^{45}$ and he moved on to work in the German courts, where he received information from Leibniz about Savery's steam-engine. For some reason he returned and attended meetings after March 1707/8. Although his proposals for engines (and for the Society's investment in them) were impractical, ${ }^{46}$ his cold reception, particularly from Newton, is striking even in the light of his connection with Leibniz. ${ }^{47}$ Newton insisted upon being present when Papin performed, ${ }^{48}$ and the Council 'thought it not proper to engage $\mathrm{Dr}$ Papin in their Service by a certain Salary', although they agreed to his proposal 'to show some new experiments to the Society and to leave his Gratification to the Councill' ${ }^{49}$ In 1711 Council ordered that ' $\mathrm{Mr}$ Papin do remove his apparatus for Experiments out of the Kitchen, which will be necessary for Mr Hunt', and the question 'whether Mr Papin should have ten pounds for his services' went to a ballot. ${ }^{50}$ Papin finally retired from the unequal struggle for livelihood late in 1712, after a derivative proposal to soften fruit and nuts in his digester, and he died in obscurity shortly afterwards. ${ }^{51}$ Papin provides the best example of the perilous position of the gifted 'scientist' who, in a society which could not recognize genius coupled with financial dependence, was in constant danger of being reduced from conditions of service to those of servitude and servility.

Henry Hunt (d. 1713) was the Society's operator and general dogsbody who rose to become 'Keeper of the House, Repository and Library' at a salary of $£ 40$ p.a. Usually unnamed in the minutes, no natural philosopher and never a Fellow, Hunt became visible at times of crisis in the provision of experiments. He is first named in 1683 when Martin Lister, who wanted to counter Hooke's programme of mechanical experiments, employed him to perform before the Society. Under Newton's presidency Hunt provided the major experimental support for Hauksbee and in 1711, as mentioned above, was preferred to Denis Papin. ${ }^{52}$ In June 1713, shortly after Hauksbee's death, Hunt was perfunctorily referred to as 'being dead since the last meeting'. The listed duties of his successor, one Alban Thomas, included cleaning, escorting visitors, collecting monies, and to 'deliver out the orders of the President and Council ${ }^{33}$

Edmund Halley (1656-1742) had been a somewhat genteel Fellow since 1679, but a family dispute soon left him apparently in financial difficulties and he began to take up paid positions at the Society. In 1684 he was appointed 'in the manner of a curator; and he was

45 According to the DNB, Papin 'sought the more lucrative post of secretary, but Halley was elected in his stead'. I find no record of this in Birch, op. cit. (21), but it would confirm the use of such positions by wouldbe professional experimenters.

$46 \mathrm{JB}, 17 / 3 / 07-8,179 ; \mathrm{JB}, 14 / 4 / 08,182 ; \mathrm{JB}, 21 / 4 / 08,184$; JB, 18/5/09, 214; JB, 26/4/11, 278-80.

47 According to the DSB, Leibniz wrote to the Royal Society Council about Papin in February 1707/8.

$48 \mathrm{JB}, 14 / 4 / 08,182$. Newton referred discussion of Papin's payment to Council on 27/12/11. Unlike other projectors and instrument makers such as Kerridge and Fahrenheit, Papin was already a Fellow and did not need permission to attend meetings.

$49 \mathrm{CM}, 22 / 12 / 08,158 ; \mathrm{CM}, 23 / 2 / 09,160$.

$50 \mathrm{CM}, 2 / 8 / 11,192 ; \mathrm{CM}, 4 / 1 / 11-12,199$. Unlike other ballots of the period, the result was not recorded nemine contradicente.

$51 \mathrm{JB}, 16 / 10 / 12,421$.

52 Hunt performed experiments, for example, on gunpowder (JB, 15/3/03-4, 67), sulphur (JB, 28/2/04-5, 97), a pike $(\mathrm{JB}, 7 / 11 / 06,114)$, magnetism $(\mathrm{JB}, 19 / 12 / 05,116 ; \mathrm{JB}, 10 / 4 / 06,128)$ and on temperature (JB, 12/1/08-9, 203). For Hunt's earlier assistance to Lister, see Pumfrey, op. cit. (14), 35-6.

$53 \mathrm{JB}, 25 / 6 / 13,500 ; \mathrm{CM}, 29 / 6 / 13,211 ; \mathrm{CM}, 7 / 12 / 13,215$. 
informed, that he should be considered for it as others had been'. He began with magnetic experiments, and continued until 1691 . In 1686 he won what the statutes describe as the 'laborious' office of clerk, which carried $£ 50$ p.a. and required the resignation of his Fellowship. As his situation consolidated he ceased his public experiments for the Society. ${ }^{54}$

Francis Hauksbee the elder (c. 1666-1713) was a one-time apprenticed draper. Probably an established instrument maker by 1704 , he emerged from obscurity as Newton's operator (or 'servant') and as a public demonstrator for lectures at Ayers Writing School given by James Hodgson and, later, William Whiston. It has been suggested that he was instructed by Papin. Like Papin and Hooke he was made FRS after months of sterling service. Also like Hooke, his work was generally 'ordered' rather than 'desired' as was other Fellows'. $\mathrm{He}$ was paid according to his efforts, which were normally worth about $£ 40$ upon production of receipts. By 1710 he was famous enough to attract foreigners to Wine Office Court, and he now lectured as well as demonstrated. Hauksbee's range of employments, which certainly put him into the category of minor capitalists of the lower middle class, probably explains why the Society never granted him the regular or 'setled' office of curator, which demanded full-time service. ${ }^{55}$

Francis Hauksbee the younger (1688-1763), was the nephew of the elder Hauksbee. In his lifetime he was both less and more successful than his uncle as an experimentalist, although he has never achieved his uncle's retrospective eminence as a scientist. He seems to have begun under his uncle's wing, but by 1712 had set up as a rival maker and public demonstrator of instruments. Soon after his uncle's death in 1713 he was in partnership with his uncle's partner, the now disgraced Whiston. Desaguliers inaugurated new lectures on behalf of Hauksbee's widowed aunt. ${ }^{56}$ Hauksbee himself earned 5 guineas from the Society for his brief 'services since his unkles death he giving a receipt in full'. ${ }^{57}$ On that occasion, services were required when the Duc d'Aumont suddenly announced his desire to attend and be elected a Fellow. ${ }^{58}$ It would seem that no Fellow felt motivated, competent or suited to introduce the duke to experimental Newtonianism. They turned to a hired hand, but the younger Hauksbee seems not to have impressed. Certainly he lost an opportunity, since his rival Desaguliers became his uncle's permanent replacement in the

54 For Halley, see Pumfrey, op. cit. (14), 15-16 and C. A. Ronan, Edmond Halley: Genius in Eclipse, London, $1975,63-75$. Halley's only 'experimental' contribution after 1692 was an observation of the variation, reported in JB, $3 / 7 / 05,110$.

55 The most convenient summary of Hauksbee's life remains Guerlac's entry in DSB.

56 Stewart, op. cit. (2), 120.

$57 \mathrm{CM}, 24 / 8 / 13,212$. This is the last reference under Newton's presidency, until he re-emerged as housekeeper. He came recommended 'by divers members of the Society', but not by Newton, whose favourite was one Thomas Overton, nor by Desaguliers, who backed Thomas Glover. See CM, 4/4/23, 267.

58 Following Hauksbee the elder's last performance on 29 January 1713, experiments ceased. When on 21 May 1713 d'Aumont's arrival was announced just before the meeting commenced 'Mr Hauksbee was ordered to prepare some particular Experiments for his Entertainment' (JB, 21/5/13, 483). It was thought proper to defer the usual reading of papers for a Newtonian display, and the duke 'was entertained with severall experiments of the production of light by friction, or elasticity, of the mutuall Attraction of the Parts of Matter, of the curve caused by the Rising of a Fluid between glass planes, etc.' Sloane stalled by showing curiosities in the repository, and contributed an 'experiment of the Stone called Oculus Mundi'. Whilst the attendance of 'Mr [George] Berkeley, a clergyman' did not provoke experimentation, the return of d'Aumont panicked them into a repertoire of air-pump experiments, presumably again by Hauksbee junior. See JB, 11/6/13, 492. 
Society. He nevertheless returned as the Society's keeper and clerk in 1723, winning a gruelling and ungentlemanly selection procedure occasioned after Alban Thomas had absconded. He did not experiment and never obtained a Fellowship, although his office precluded that honour. ${ }^{59}$ The lack mattered less as commercial science expanded, and Hauksbee became an active partner in several lecturing, inventing and patent schemes.

Jean Theophilus Desaguliers (1683-1744) is one of the better known experimenters. Larry Stewart has firmly established his roles in the lecturing community and the Royal Society. His father was a Huguenot refugee and minor London schoolteacher. Desaguliers went to Oxford and, after proceeding BA, briefly took over the lectures in experimental philosophy of John Keill, with whom he had studied. Economic necessity, caused by his marriage in 1712, is the most plausible explanation for his move to London where he succeeded Hauksbee the elder, first as lecturer and then as the Society's paid experimenter. Desaguliers was first proposed as a Fellow by Hans Sloane in July 1713, but nothing had come of it before Newton proposed him a year later. In this, however, Desaguliers' career differed little from that of the other employees who lacked social status. Instead months of service commuted into Fellowship and cachet. Once elected Desaguliers was excused his fees ' $[\mathrm{i}] \mathrm{n}$ consideration of his great usefulnesse to the Royal Society as Curator and Operator of Experiments' ${ }^{60}$ The first record of his attendance shows him treated less as a virtuoso than as a servant: 'It was ordered that Mr. Aguiliers be desired to wait on the President to take his directions as to the structure of that Instrument and the Experiments to be made. ${ }^{61}$ Years later, Desaguliers could still be admonished, as Hooke had been, for the neglect of his duties. He also followed Hooke in introducing to the Society his own clients like Thomas Glover ${ }^{62}$ His income was performance related, typically $£ 30$ often supplemented with Copley's $€ 5$ donation. ${ }^{63}$

Daniel Fabrenheit (1686-1736) came from a family of bourgeois traders in Gdansk. His parents died suddenly in 1701 and he was sent to the Dutch Republic to learn commerce, where he chose the new and growing scientific instrument business. He toured Europe making contacts before establishing himself in Amsterdam in 1717, with a novel line in thermometers. He arrived before the Royal Society on 5 March 1723/4, during a phase of experimental torpor, and the 'Gentleman of Dantzick had leave to be present'. In a series

59 For details of the selection process see the fascinating $\mathrm{CM}, 4 / 4 / 23$, 267. Each candidate was 'examined in the following particulars' of handwriting, languages 'skill in Natural Knowledge or History', librarianship, and 'the sufficiency of the Security they were able to give for their Trust'. Hauksbee offered $£ 400-500$ against any misdemeanour. This was a sensitive matter because Alban Thomas had absconded leaving debts. The Society considered legal proceedings (CM, 30/11/23, 275; CM, 12/3/24-5, 276), but was ultimately benevolent (CM, $3 / 11 / 26,297-8)$. As with Halley's election to the Clerkship, the conditions imposed on the housekeeper were ungentlemanly and incompatible with Fellowship, but manifestly compatible with the performance of experimental work.

60 Note that this is not the same as Hooke's Curatorship by Office. Desaguliers was paid according to his efforts. Newton generally preferred payments to be 'esteemed as a gratuity and not [to] be drawn into a president [sic]'. See CM, 5/11/19, 251: CM, 12/12/16, 257.

$61 \mathrm{JB}, 18 / 2 / 13-14,546$.

$62 \mathrm{CM}, 17 / 11 / 26,299$. Desaguliers also introduced his co-projectors William Vream and Henry Beighton. See $\mathrm{JB}, 4 / 4 / 23,267,269$, and Stewart, op. cit. (2), 225.

63 This was initially a monetary payment only. A medal was also awarded from 1736 , which Desaguliers won. The first person other than Desaguliers to receive the $£ 5$ was Stephen Gray in 1731 and 1732. See Boas Hall, op. cit. (20), 130-1. 
of experiments up to 30 April he demonstrated his instruments for measuring temperature and specific gravity, during which time Desaguliers proposed him for a Fellowship. ${ }^{64}$ Sloane raised at Council the case of ' $\mathrm{Mr}$ Fahrenheit who had for some time made it his buisness $[s i c]$ to communicate the description of divers new Instruments by him invented for making Experiments in Natural Philosophy. And whose constant attendance on the Society seemed to require some sort of acknowledgement.' That 'sort' was determined to be a payment of 10 guineas.

Stephen Gray (c. 1666-1736) performed his major experimental work for the Royal Society after 1730. Gray's faltering career provides some of the best evidence of the Augustan tensions between scientific accomplishment, manual labour and social status. $\mathrm{He}$ continued the rise of his family of dyers from the artisanry into the middle orders, and he applied his family's values of self-education to the study of nature. He was at ease with acquaintances like Henry Hunt and John Flamsteed (his mentor and quasi-patron but also the son of a tradesman). He was less at ease with the virtuosi. When he was offered Hunt's lowly position at the Society in 1711, Brook Taylor recorded that 'the poor man [was] so very bashful that I can by no means prevail upon him to think of the business'. However, poor health made him dependent upon his connections with natural philosophers, such as Roger Cotes (whom he had assisted at Cambridge) and William Derham. He was thus stimulated to seek the Society's patronage, and in 1719 he became a 'gentleman pensioner' of Charterhouse. ${ }^{65}$

Ever since Hooke had introduced him in 1696, Gray had been known to Fellows as an observant microscopist. He contributed reports of electrical experiments in the 1700s, but they were appropriated by Hauksbee the elder, and he held back until 1720. Following his work and collaboration with the young and wealthy FRS Granville Wheler (a relationship which would make a fascinating case study in this context), ${ }^{68}$ Gray's experiments and reports produced another flurry of activity at the Royal Society, which led to his own election in 1732. Like the other poor but diligent experimenters, it was agreed at the same time that he should be excused all fees and payments 'and that he should have the five pounds paid him, which were left by Sir Godfrey Copley, for the experiments he made for the year 1732 ' ${ }^{67}$ The Society was keen to encourage him but Secretary Mortimer found him dying in Charterhouse.

\section{OTHER PAID 'CURATORS'}

These twelve good men were responsible for all but a fraction of the Society's experimental activity during this period. They all literally 'curated' experiments but, given the flexible and evolving meaning of curatorship, they were not all formally appointed as 'Curators' by the Society. Others, even though they did little work, were appointed or paid to fill this position. For completeness, they were:

Nehemiah Grew (1641-1712). Grew was appointed 'curator of the anatomy of plants' in 1672. His father was a Coventry non-conforming clergyman who resigned in 1662 . Grew

$64 \mathrm{JB}, 5 / 3-30 / 4 / 24,443 \mathrm{ff}$.

65 I have not studied Gray's work after 1730, and my account relies upon those of Heilbron, op. cit. (18) and op. cit. (21), and his entry in DSB, s.v. 'Gray, Stephen'.

$66 \mathrm{I}$ am grateful to Simon Schaffer for this suggestion.

$67 \mathrm{CM}, 28 / 2 / 32-3,122$. 
may have developed an unlicensed medical practice because he satisfied the Leiden Faculty of Medicine (Cambridge being closed to dissenters) with a dissertation De liquore nervoso in 1671. Recognizing a man both gifted and needy, Hooke proposed him for a Fellowship, and the Society offered a second paid curatorship. This entailed Grew abandoning his Coventry practice for a maximum income of $£ 50$, or whatever subscriptions the Society could raise. Grew informed Oldenburg that the income 'would not (as I have tryd) have amounted to the profit... from my practise in the Country'. The subsequently chequered history of Grew's project follows the Society's ability to find funds for him. 'Why Grew's contribution to the business of the Society virtually ceased in the summer of 1679 is not known', writes Hunter, although he suspects that, as with other physician Fellows, it 'was due to an increasing preoccupation with other business' ${ }^{68}$

'Dr' James Douglas (1675-1742) was, on one occasion in 1707, ordered a payment of $£ 10$ for dissections. ${ }^{\theta \theta}$ The Society's Journal Book is not informative about what Douglas did, although he was given a Fellowship in the November 1706 elections. It is possible, then, that Douglas was one of the climbers who first impressed with a few performances, was then rewarded with a Fellowship (and money), after which he traded on the prestige of membership and fell idle.

John Lowthorp (dates unknown ${ }^{70}$ ) is another 'curator' who does not fit my pattern. He also left no visible trace of any work. His case is an interesting one because he was in the group of councillors, which included John Harris and John Van de Bemde and which was led by John Woodward, whose resistance to the Newton-Sloane domination of the Society came to a head in March 1710. ${ }^{71}$ It seems that in November 1708 Council debated the merits of Hauksbee's, and by implication Newton's control of the experimental programme. 'It was ordered that $\mathrm{Mr}$ Hauksbee should go on and show experiments for the next year, and that the Councill of the Society will pay him as he deserves. It was desired that $\mathrm{Mr}$ Bemde should signify the same order to Mr. Lowthorp.' Lowthorp was immediately excused his subscriptions, presumably in recognition of the experiments he would perform. ${ }^{72}$ However, none are recorded and, once the rebels had been routed, 'it was ordered that $\mathrm{Mr}$ Lowthorp be demanded his contributions from the last time he was excused, viz. from the 28th of January, 1708/9.$^{73}$ It is not unreasonable to read these events as an attempt to mount a non-Newtonian experimental programme, which failed not least because gentleman Fellow Lowthorp proved unequal to the work. One might read in the same light the arguments over Papin's return, and Newton's resistance to it. If so, then these are intriguing signs of opposition to the way that President Newton employed first Hauksbee and then Desaguliers to turn the Society's limited work in experimental physics into a consolidation of his own programme.

68 Hunter, op. cit. $(20), 1989,261-78$, quotation from 276. This account relies substantially on Hunter's thorough study.

$69 \mathrm{CM}, 2 / 7 / 07,144$, when Hauksbee also received $£ 40$ 'for his last years waiting upon the Society'. See also The Record of the Royal Society of London for the Promotion of Natural Knowledge, 4th edn, London, 1940 , 30 .

70 I have been unable to determine his dates. They are missing from the otherwise full index of Boas Hall, op. cit. (20).

71 Westfall, op. cit. (22), 673-5.

$72 \mathrm{CM}, 3 / 11 / 08,156 ; \mathrm{CM}, 12 / 1 / 08-9,159$. Emphasis supplied.

$73 \mathrm{CM}, 12 / 7 / 11,192$. 


\section{AUGUSTAN EVALUATION OF EXPERIMENTAL WORK}

From these labour histories, those of Slare, Tyson and Lowthorp stand out as exceptions. It appears that they were more gentlemanly Fellows who represented factions of the Society dissatisfied with its reliance upon the work of one employee. Their effectiveness in altering the experimental agenda was very slight. The remaining twelve histories show remarkable degrees of commonality, which can usefully be summarized before moving on to their significance in Augustan society.

First, experimental work had connotations of mechanical service. The Sociery's experiments were performed not by virtuoso gentlemen, but by middle-class men of trade and employment who were their social and economic inferiors. The performers were emergent 'professionals' of the same social stratum from which science lecturers were drawn. Indeed, most were themselves involved in public demonstration. They all depended for their livelihood, certainly at first, upon the small incomes available from the Society's curatorships, lecturing, operating for philosophers or instrument making.

It is, perhaps, no surprise that the Society's experiments were primarily performed by those whom it paid, but the payments must be put into context. The gentleman curator like Slare, a rare species after 1665 , was reimbursed for the sacrifice of his leisure. ${ }^{74}$ By contrast, the chief workers came from straitened circumstances, and were trying to climb up the middle orders of society using the novel route of professional public experiment. Hooke's, Hunt's, Hauksbee's and Gray's impoverished origins are indisputable. Grew nearly rejected his position, and Lower actually did so, because they could not afford to abandon fledgling medical practices for the Society's small and unreliable stipends. Halley and Fahrenheit both failed to receive expected family inheritances, and found alternative careers in natural philosophy. Henry Hunt was the Society's dogsbody. The Huguenot émigrés Papin and Desaguliers, despite university educations, depended upon high-risk scientific patronage. Their fortunes fluctuated but in both cases when their patronage dried up they declined, and they apparently died in poverty. ${ }^{75}$

Thus the Society left its experimental orders with men who were described as useful, 'fit for employment' and 'service' or, in Fahrenheit's case, in 'constant attendance on the Society' which was valued at 10 guineas. ${ }^{76}$ Conceding that the minutes adopt a consistently formal style, it must be noted that the language of employment and service was never applied to the leisured gentleman experimenter. Nor were virtuoso Fellows personally rebuked for dilatoriness. ${ }^{77}$ All this points to a systematic and significant pattern of behaviour influenced by Augustan norms of the master-servant relationship. The service

74 Pumfrey, op. cit. (14), 9.

75 For Papin, see DSB, s.v. 'Papin, Denis'; for Desaguliers' decline see L. Stewart, 'Public lectures and private patronage', Isis (1986), 77, 47-58.

76 For Fahrenheit see CM, 7/5/24, 279. '[Fahrenheit's] constant attendance upon the Society seemed to require some sort of acknowledgement' which was 10 guineas. Fahrenheit was another who arrived as an unknown, was 'given leave' to attend meetings because he was not a Fellow, and provided experimental entertainment, as recorded in JB, 5/3/23-4, 443'; JB, 26/3/24, 454; JB, 2/4/24, 457; JB, 23/4/24, 467 and JB, 30/4/24, 470. Having performed thermometric experiments and demonstrated instruments, Fahrenheit was proposed for a Fellowship by Desaguliers at the meeting of $26 \mathrm{March} 1724$ and subsequently elected.

77 See Pumfrey, op. cit. (14), 7 and 38 n26 and CM, 17/11/26 for Hooke's and Desaguliers' rebukes. 
in question was not to the abstract master of 'science' but to the corporeal masters of the President and Fellowship.

Secondly, and more contentiously, I conclude that employees were not recognized as experimental philosophers. Sceptics might argue that the Society's virtuosi considered scientific ability, and their own forum, to be peculiarly independent of the issues of social status and hierarchy. Good minds were surely recruited and welcomed wherever they could be found. This counter-argument could be extended to suggest that, since the gentlemen Fellows needed no recompense, it was an act of benevolence to cede the pleasure of experimenting to needy individuals. But the evidence of the Society's statutory/minuted and quotidian/actual treatment of them belies the point. Besides, there is the chronology of their election to Fellowships: the biographies show how they were only elected once they had proved the value of their service, despite their apparent status (to us) as 'notable scientists'. The exceptions here are Slare, Tyson and Halley. Halley, extraordinarily, was compelled to resign his Fellowship when he became clerk, and his successors, Thomas and Hauksbee junior, were never considered for election. One might have thought that, in a period when elections were scandalously frequent and experiments scandalously rare, anyone proven or even rumoured to be an adept experimenter would have been enrolled. And yet, when the Society needed an experimentalist, it was forced to recruit outside and below its ranks to men frequently of unknown or uncomfortable provenance. Whereas gentlemen Fellows' honour and worth were presumed, mechanical men were subjected to rigorous investigation.

Thirdly, there is very little evidence that the Fellows of the early Royal Society invested the practical activity of performing publicly verifiable experiments with any real commitment or dignity. ${ }^{78}$ They freely engaged in the genteel or manly exercises of geometrizing, calculating, exhibiting and discoursing, even discoursing on the necessity of experiments to real philosophy. But, with the partial exception of Newton, they watched while others were paid for the dirty, sweaty mechanical work. In the triangle of reason, labour and status, the Fellows were radical in allowing reason to confer status: the Royal Society proclaimed by its very existence that scholarship and gentility were compatible. But they were conservative when they differentiated paid, labouring 'professional scientists' from experimental philosophers. 'Promoting Experimental Learning' did not mean performing experimental work.

Given the above, early obscurity, poor treatment and constant worries about poverty and rejection turn our to be the typical profile of an Augustan experimenter, and nowhere near as surprising as some historians have thought. Nor is the spasmodic nature of the Society's experimental programme; and we can abandon our perception of the early Society in a permanent experimental crisis or decline. Once Fellows stopped curating after 1665 , the Society's programme depended upon the circumstances of a few individuals, and their ability to retain the Society's favour. In the rare cases where they achieved partial recognition for their work, it depended upon their ability to use their achievements to transform their ascribed status of servant into the de facto status of natural philosopher.

So great are the similarities between the twelve that one is tempted to construct an ideal type of Augustan experimental worker. He is born (perhaps without historical trace) into

78 Though this is not to deny that they did experiment privately, and occasionally publicly. This is discussed below. 
a family of the middle orders, which is aware that in England education and commerce offer ever-expanding opportunities for self-help and social advancement. He develops his skills in experimental philosophy by serving a patron, often a Fellow of the Royal Society, as Hooke served Boyle, or Gray Roger Cotes. He is introduced by a patron to the Society when it needs a curator, housekeeper or other servant. He works diligently for some months, after which his labour is rewarded with money and a Fellowship. He is allowed to publish his work in the Philosophical Transactions, or he writes it up as a book of natural philosophy, as Papin did with his Digester. This produces a reputation in London and abroad as an experimental philosopher. He cashes in the credit through bigger instrument sales, lecture subscriptions, consultancy and clientage contacts, and other positions over which Fellows have influence. For Hooke and Halley, these also included a better position within the Society itself. Foreign observers now mistake him as a jewel in the Fellowship's illustrious crown. Success reduces, but never removes the obligation of service to one's colleagues. But his success elsewhere brings about a crisis in the supply of experiments, and the Society looks for a new man. He tries to advance his own trainees and contacts, as Hooke did for Papin, Hauksbee for his nephew, and as Desaguliers tried to do for Glover. Hooke, Papin, Desaguliers and Gray, moreover, all explicitly used the Society to gain outside positions, but in this they were no different from (although more experimentally industrious than) the increasing numbers of would-be professionals, especially medical men like Lower and Douglas and possibly Grew, who sat on the benches until they had acquired the polish needed by a successful physician.

But an emphasis upon commonalities and an ideal type gives the false impression that the community of paid experimenters changed little from the $1660 \mathrm{~s}$ to the $1720 \mathrm{~s}$. In actuality, individual, structural and intellectual relations were transformed. Newton's imperious presidency created a very different climate and role for experimentation from that of Hooke's heyday. Structurally, the fact that Augustan England witnessed the working through of many of the tensions of a commercializing society improved the position of the paid, public science demonstrator within the changing triangle of labour, reason and status. The intervening development of commercialized science crucially altered the kinds of service expected, and of experiments performed. This in turn led to a greater philosophical value being placed on the work, and the workers.

\section{PUTTING MEN IN THEIR PLACE - THE VIEWS OF LOCKE AND SPRAT}

In a modern, scientific society it makes little sense to ask whether Robert Hooke was an experimental philosopher or a mere experimenter. To Augustans, even to a progressive, pro-commercial Whig theorist like John Locke, it was an ideologically crucial question. Locke's vision was of a polity radically divided into two distinct sorts of men. In his Second Treatise, Locke stated:

God gave the World to Men in Common; but since He gave it them for their benefit... it cannot be supposed He meant it should always remain common and uncultivated. He gave it to the use of the Industrious and Rational, (and Labour was to be his Title to it;) not to the Fancy or Covetousness of the Quarrelsom and Contentious. ${ }^{79}$

79 Locke, op. cit. (10), 309 (\$34). 
Whilst his insistence upon labour as man's title is evidence that Locke's state of nature is no Eden of Tory paternalism but remarkably like the commercial, 'improving' society evolving in his own time, scholars disagree about the assumptions which permitted Locke to discount the 'Quarrelsom and Contentious' majority. MacPherson counters readings of Locke as a liberal democrat by drawing attention to Locke's denial of citizenship and even reason itself to the vast majority of men (and, we might add, to all women - explicitly and implicitly respectively). Instead, he reads Locke as a thoroughgoing theorist of early capitalism, for whom 'irrational' labourers alienate their labour to bourgeois entrepreneurs. ${ }^{80}$ Tully, in an acclaimed study of 1980, argues that MacPherson has misinterpreted Locke's concept of the labour relationship: 'All that Locke assumes is the master-servant relation. It is not ... the wage relationship of capitalism. ${ }^{, 81}$ Tully notes that Locke himself described the relation 'Master and Servant', making the servant a free man:

a Free-man makes himself a Servant to another, by selling him for a certain time, the Service he undertakes to do, in exchange for Wages he is to receive: And though this commonly puts him into the Family of his Master, and under the ordinary discipline thereof, yet it gives the Master but a Temporary Power over him. ${ }^{\text {s2 }}$

Tully is persuaded that Locke's servants are like craftsmen, who can perform their work undirected. They differ from apprentices, whose genuinely servile treatment in the period flowed from their dependence upon a master's direction. ${ }^{83}$ Servants do not, therefore, alienate their capacity to labour, but only the labour embodied in a complete service or commodity. It goes without saying that, in this sense, the product together with the embodied labour is the master's. Tully considers that this 'social division of labour ... was the dominant and non-capitalist mode of production until at least the late eighteenth century ${ }^{84}$ Keith Tribe, however, suggests that writers like Locke were necessarily adopting and adapting pre-capitalist discourses of labour and property to a changing reality. ${ }^{85}$ Neal Wood has developed the criticism much further. Where Tully concluded that Locke's theory of property was 'consistent with the proposals put forward by [the Levellers, proposals which attempted] to ensure the widest possible distribution of private property', Wood responds that '[o]n the basis of what we know of Locke and his age, Tully's argument... simply transcends the bounds of common sense and empirical evidence'. Wood reasserts Locke as, inter alia, an ideologist of capitalist appropriation but, in an important development from MacPherson's view, one specifically of agrarian capitalism. ${ }^{86}$

In my opinion, Wood's reading has the strength of locating Lockean theory within the context of Locke's and his allies' wider ideas and actions. He argues that Locke's

80 Macpherson, op. cit. (13).

81 Tully, op. cit. (9), 136.

82 Tully, op. cit. (9), 136; Locke, op. cit. (10), 340 (\$85).

83 One might speculate, in this regard, whether Newton, for example, thought of Hauksbee as an apprentice natural philosopher, when he directed him in the design of instruments and experiments.

84 Tully, op. cit. (9), 140.

85 Tribe, op. cit. (13), 51.

86 Tully, op. cit. (9), 169; Wood, op. cit. (13), 75. 
opposition to the paternalism of Tory landowners and his adoption of the agrarian capitalist ethic of improvement required the active, interventionist, 'labour' theory of property. He thus established new criteria for new classes of a landed élite. It is well known that elsewhere in Locke's writings, not least in his harsh prescriptions for dealing with the poor, he made no concession to a radical 'levelling' extension of his theory (as Tully would have it). ${ }^{87}$ To do so would have destabilized the emerging élite to which he belonged. His solution, of denying citizenship, rational reflection, indeed full humanity, to the labouring classes may seem contradictory and blatantly ideological, but it was a solution. 'The labourer's share [of the national income, he wrote], being seldom more than a bare subsistance, never allows that body of men, time, or opportunity to raise their thoughts above that [subsistence]. ${ }^{98}$

How does this bear on the Royal Society? We have seen just how problematic the questions of paid employment, service and labour were in a rapidly commercializing economy. When we couple this ideological sensitivity to the evidence that paid experimenters were treated as servants, we are surely forced to conclude that men like the elder Hauksbee and Desaguliers were real anomalies. Secondly, even progressive theorists like Locke assumed the terms of an increasingly dysfunctional 'classical' discourse of socio-economic relations, in which paid, manual labour debarred one from the small group of a rational, politically active gentlemanly élite. Thirdly, the conception of paid experimental work as service in the traditional sense is indispensable to our understanding of intellectual, scientific property in the Augustan age. In contemporary ideology, landed individual patrons like Robert Boyle, or gentlemanly collectives like the Royal Society, could assume that air-pumps, chronometers, experimental demonstrations or even natural philosophical discoveries made in their service, not to say under their masterly 'direction', ${ }^{89}$ were their property. We might note that much of Hooke's chronometric research, which he claimed was being stolen, was done in his capacity as an employed curator.

Locke would surely have denied Hooke's claim. Despite the physical equivalence of the labour in 'the Turfs my Servant has cut; and the Ore I have digged', when Locke appropriates the turves he denies any moral equivalence. The denial invokes deeply embedded, conservative Augustan moral distinctions between the supposedly selfinterested, irrational labourer, and the virtuous gentleman of property.

We can see this Augustan ideology explicitly invoked on behalf of the Royal Society by Thomas Sprat. In his semi-official History of the Royal Society, Sprat propounded the Society's utilitarian aim of encouraging and advancing the mechanical arts and sciences. This ideology of rational, commercial improvement was similar to Locke's, and similarly carried the risk of quasi-levelling, proto-radical readings. It risked the elevation of mechanics such as instrument makers into natural philosophers. This was neither the Fellowship's intention nor its practice. However, Sprat employed a similarly contradictory,

87 Locke variously described the lower orders as 'destined to labour and given up to the service of their bellies', and who, in religion, 'cannot know and therefore must believe'. See Macpherson, op. cit. (13), 223.

88 Macpherson, op. cit. (13), 223.

89 The Society's minutes frequently record the direction of experimenters by the virtuoso philosopher. See, for example, JB, 18/2/13-14, 546, where the airy Desaguliers was 'desired to wait on the President and take his directions'. 
conservative Augustan ideology to Locke in making his escape. The Society wished to encourage the mechanical arts whilst discouraging the mechanics themselves. In order to show that 'Mechanics are improvable by others besides Tradesmen', Sprat observed that:

Tradesmen...chiefly labour for present livelihood, and therefore cannot defer their expectations so long, as is commonly requisit for the ripening of any new contrivance... Whereas the men of freer lives, have all the contrary advantages. They do not approach those Trades as their dull, and unavoidable, and perpetual employments, but as their diversions. ${ }^{90}$

As with Locke's cutters and diggers, the manipulation of apparatus by mechanics and by mechanical philosophers might look physically identical, but they were morally different. Consequently, according to Sprat, the advancement of mechanics required 'the light of men of Knowledge, to be a constant overseer, and director, of the industry, and works of those that labour'. He mused over a future Solomon's House, 'when either Mechanick Laborers shall have Philosophical heads; or the Philosophers shall have Mechanical hands' ${ }^{,}{ }^{91}$ but for Sprat, as perhaps for Locke, such men were futuristic mutants. Yet is not a mutant, who adds to his mechanical hands a philosophical head, an excellent description of the science lecturer or public demonstrator of experiments? As Sprat, Locke and other Augustans sensed but could not acknowledge, the monsters of professional experimental science were already in their midst.

Sprat's and Locke's classical moral distinction explicitly permitted gentlemen to play at mechanics and at being mechanics. It is not argued that Augustan ideology prevented them from experimenting. This would fly in the face of the evidence, particularly from the Society's first meetings. Virtuosi could choose to experiment in public, and also in their private laboratories. ${ }^{92}$ What the moral ideology did not permit was for them to do it 'professionally'. Conversely, it ruled out the paid experimenter from the community of philosophers.

The point is that, whatever the Fellows' rhetoric encouraged in principle, the practice of the Society evolved to devolve the work to its paid servants. Many of the famous experimental achievements of its 'Golden Age', such as the development of pneumatics, the consolidation of Newton's mechanical and optical theory and the new science of electricity, depended wholly on their labour and in no small part on their genius. Although the rhetoric of experimentalism was created by gentleman philosophers, the practice was forged by their inferiors, to whom the ingredients of sustained labour, physical manipulation, mechanical mindedness and 'intercourse with tradesmen' were closer to hand.

The new situation exposed the now familiar contradictions in the old ideology. Was a paid demonstrator like Hauksbee or, earlier, Hooke a servant of or an equal with his paymasters? Was Desaguliers primarily a labouring hand or a philosophical head? Did he do experiments or experimental philosophy? Did the rewards from these men's labour and

90 T. Sprat, A History of the Royal Society, London, 1667 (reprint edn, London, 1959), 391-2, 404.

91 Sprat, op. cit. (90), 397, 396, 427.

92 It would, however, be instructive to re-examine the distribution of private experimental work. We need to determine the extent to which gentlemen acted as philosophical overseers of operators, whose contributions become invisible in the public reports. 
the intellectual capital belong to them, to the Royal Society, or to the Republic of Letters? The questions were hard, and getting harder as paid professionals proliferated.

Those questions, however, were by no means confined to experimental philosophy. They reflected, in a very sharply focused way, problematic changes in relations of class and in the relations between reason, status and labour. What had already been in Hooke's time tense, unstable demarcations, broke down further as commercialization, including the commercialization of science, continued the evolution of England's social structure. We might conclude that the conversion of experimentalist rhetoric into entrenched social practice required such an evolution. In the history of science, the fossil records of the early Royal Society begin with virtuoso curatorship. There follows an unstable period where a lower species is allowed to take over, and it concludes with the growth of a new habitat, with fewer barriers to interbreeding. The habitat, which Larry Stewart has called 'public science', is populated by lecturers-cum-philosophers-cum-demonstrators. The rise of public, experimental science was intimately linked to the rise of commercial society but, by successfully negotiating the contradictions which were so evident in it, it also acted as a spur to development.

\section{THE CHANGING PLACE OF THE PAID PROFESSIONAL}

This final section attends more closely to some consequences for the Royal Society of the co-evolution of professional science and commercial society. A major change was effected by the expanding structure of professional science. By 1730 the range of occupations available within this area had broadened and differentiated into a recognizable professional hierarchy. The ladder afforded an ascent into the pseudo-gentry which had not existed in the seventeenth century. With the increased numbers, and the improved levels of wealth and status for instrument makers, scientific lecturers and consultants, came increased social mobility and diversity. In consequence experimental curators and demonstrators could now emerge from various social strata. No instrument maker was elected FRS in the seventeenth century, when even the excellent Joseph Moxon was blackballed. Restoration England had not developed the social dynamics that in the earliest years of the eighteenth century allowed a draper like Hauksbee and a dyer like Gray to offer professional scientific services and to obtain formal equality with virtuosi. Contemporaries tried to distinguish between the likes of Hauksbee, Keill and Desaguliers, but with increasing difficulty. Each had a claim to be doing genuine experimental philosophy. The new era of the science lecturer, in which public science came of age, ended the old era of the exclusively gentleman philosopher, in which experimental science had been developed.

Secondly, commercialization and professionalization eroded the early Society's apparent concern to separate science as public duty from science as private profit. Sprat's distinction between interested 'tradesmen' and disinterested virtuosi, which Hooke was already, if uniquely blurring, became unworkable in the late Augustan climate. Meetings of the Society came to combine readily fruits from philosophy with those from the business of coffee-house entertainment or of technical consultancy. This was because a demonstrator like Desaguliers moved freely between various domains, and transferred practices from one to the other as he sought to please the Fellows. Such transfers help to explain two characteristics of Augustan science. 
One characteristic is the prominence of the lecturer's demonstration experiment. Hauksbee's genius for producing apparatus which turned ephemeral and feeble phenomena such as phosphorescence and electricity into visible public spectacles was an essential component of the Newtonian programme to explore the hidden active principles of nature. Desaguliers excelled at well-designed demonstration experiments which tested and removed ambiguities, and this didactic skill fitted well with Newton's belief in incontrovertible experimental deductions. However, serious, pedagogic Newtonianism could also shade into showmanship. Desaguliers, for example, interspersed important, but dull optical experiments with his 'Newton's cradle', a combination of demonstration and display. He also showed experiments to imitate the feats of the circus 'strong man' with a system of pulleys, an item doubtless taken from the top drawer of his crowd-pleasers. The Fellowship, uniquely, desired them to be repeated. ${ }^{93}$

A second characteristic was the intrusion of the world of projecting and technical consultancy as the lecturers whom the Society employed brought their projects and schemes with them. Under Newton, the Society attempted to keep itself free from commerce, but the pressure of the experimenters' financial interests produced inconsistencies. A proposal from Papin, that they 'Erect a Company or Society for New Inventions for which Subscriptions may be made for 1000 stock' (beginning with his Digester), from which he would get 10 per cent of profits, was dismissed..$^{94}$ Yet the Society was simultaneously negotiating the profitable right to scrutinize all patents. ${ }^{95}$ Similarly, it rejected requests for patronage and support from 'necessitous' engineers as improper, ${ }^{96}$ while Desaguliers was allowed to announce a private show during a meeting, and advertised his patent fireplace using as endorsement one he had installed at Crane Court. ${ }^{97}$ After Newton's death, Desaguliers shifted the emphasis of his demonstrations towards the commercial applications of Newtonian mechanics. Fellows understood the value of this, and the majority of subscribers to the second volume of Desagulier's Course of Experimental Philosophy insisted upon the replacement of Newtonian optics by 'the Consideration of Water-Engines' $!^{98}$

Robert Hooke would surely have envied such free play between the Society and a secure commercial sector. He had been in constant dispute with the Society over benefits arising from his work, and worried about revealing his inventions to them. Curator Hooke had accepted exclusive employment - he had no alternatives in the 1660 s - and he was brought to heel by the Society until the 1670 s, when his fortunes improved and he could afford to ignore its complaints. But in the eighteenth century, the Society recognized that, while

$93 \mathrm{JB}, 10 / 6 / 14,574 ; \mathrm{JB}, 21 / 7 / 15,78$. Such experiments were accompanied with references to the principles which they demonstrated. In the following paper in this issue Schaffer suggests that these particular experiments related to claims for perpetual motion machines (see S. Schaffer, 'The show that never ends: displays of perpetual motion in the early eighteenth century', BJHS (1995), 28, 157-89).

$94 \mathrm{JB}, 26 / 4 / 11,278-9$.

95 See Stewart, op. cit. (75), 201.

96 A water engineer called Kerridge, who is not mentioned in Stewart, op. cit. (2), made three entreaties to the Society. First he asked for recommendations, which Fellows considered giving, but as individuals and not as from the Society as a whole. He returned to offer his services, without result, and then appeared two years later pleading his 'necessitous condition'. He was informed that the Society did not deal with such petitions. JB, 3/7/12, 412; $\mathrm{JB}, 30 / 10 / 12,425 ; \mathrm{JB}, 22 / 4 / 14,562$.

97 JB, 24/6/14, 8; JB, 3/11/15, 84; CM, 8-14/4/19, 247-8; Stewart, op. cit. (2), 225-8.

$98 \mathrm{~J}$. T. Desaguliers, A Course of Experimental Philosophy, Volume Il, London, 1744, Preface. 
science was truth, it was now also business, and it assumed that its employees supplemented their income with a portfolio of offices.

In passing, the Society's assumption provides the answer to the often posed question of whether Hauksbee and Desaguliers were ever officially 'Curators'. The statutes, for which Newton was a stickler, specified that the Curators by Office could not engage 'in any other employment '. ${ }^{99}$ Hauksbee and Desaguliers arrived already profiting from public lecturing and demonstrating. The statutes allowed for men, like them, 'engaged in other employments [who] may yet be of usefulness to the Society'. Such men could not hold a Curatorship by Office, but only plain curatorships. They could not receive a salary, but payment 'proportionable to the time bestowed in service', a system which Hooke had advocated in the 1670s and which was later implemented. ${ }^{100}$ Consequently, one of Newton's annual tasks at a summer meeting of Council was to decide how much work Hauksbee or Desaguliers had done, and how much they deserved. ${ }^{101}$

By 1730 we can see the easing of some of the explicit tensions between natural philosophical work and social status, and the creation of a more comfortable world for the likes of Desaguliers. The old ideology linking labour, reason and status had become dysfunctional. More and more Englishmen were adopting the ideology of Desaguliers' patron, Richard Steele, and agreed that reason (albeit Locke's highly political notion of reason) counted for more than breeding. ${ }^{102}$ In this context, it made less sense to worry about 'who did the work?'

\section{CONCLUSION : LECTURERS OR PHILOSOPHERS?}

Did these changes turn every experimental worker into a credible natural philosopher? Were even public lecturers 'all scientists now'? Some Tories continued to deny that commodified philosophy was philosophy at all. I conclude, as I began, with the contemporary assessments of Hauksbee.

When Desaguliers wished to place himself above Hauksbee, he was in a position to invoke neither considerations of birth and status, nor the impurity of trade. Instead, he refused to dignify Hauksbee's work with the title of philosophy because it was not 'rational' like his own. Because Hauksbee's experiments were 'not made use of as mediums to prove a series of philosophical propositions in a Mathematical Order, they laid no such foundation for true Philosophy as Dr. Keill's experiments' ${ }^{103}$ Desaguliers could not pretend that his work was untouched by commerce, but he chose to present the newly commercialized profession of science lecturing as peculiarly above other trades and professions. He traded in reason - a market where, he claimed, the normal ungentlemanly rules did not apply.

[Others'] Discoveries become an advantage to myself; for what would raise envy in any other profession, but that of a Philosopher, is received as a new Acquisition by all Lovers of Natural

99 Pumfrey, op. cit. (14), 13.

100 Pumfrey, op. cit. (14), 8-10. The evidence of Hauksbee's and Desaguliers' employment and reward shows that the system was adhered to in the eighteenth century.

101 Newton did not pay them 'by results' (in Heilbron's understandably loose words), but according to the model of service.

102 For Desaguliers and Steele, see Stewart, op. cit. (2), especially 265-7.

103 Desaguliers, op. cit. (16), Preface, p. cv. 
Knowledge, the Profit being shared in common, while the Discoverer has only the Honour of the Invention... For this reason, I never scruple making use of Machines and Instruments contriv'd by others, nor was I ever shy of communicating, or even lending my own. ${ }^{104}$

This was nonsense. Ten years later, poorer and disillusioned, he complained that his inventions and profits had been stolen by the unscrupulous. As Stewart shows, Desaguliers eventually found the commercial world tough going, but it was precisely to this world, where the distinction between civic virtue and common trade was disappearing, that he and the other Georgian lecturers owed their existence and esteem.

Unlike Desaguliers, when Hauksbee compiled his book of public experiments he did not claim that he was a philosopher. In his preface, he portrayed himself as a man well aware that he was unequal to the natural philosophers whom he served. His Physico-Mechanical Experiments present (as Desaguliers claimed of his lectures) a series of 'surprizing phenomena', produced by 'so undeserving a person' and one who was 'very sensible [of] the imperfection of my performance and my want of a learned education'. The authority of the experiments came not from him, but from his masters - the work had 'been already read and approved before the Society', which he hoped would 'overcome the disadvantage of coming from the hands of so undeserving a person'.

The authorial voice of the descriptions is that of an uninformed observer who is, therefore, constantly 'surprized'. Hauksbee ventured some comments in an appendix, but generally presented his experiments as the observations of an unlearned mechanic. They 'will (I hope) be of some use to the Intelligent Philosophical Reader'. ${ }^{105}$ We could agree with Hauksbee and apply to him, as he did to himself, the conventional, classical standards of Augustan England. If so, then he and his like may have done the experimental work, but they were not experimental philosophers. We might say that he became one to later generations, more distant from, or blind to the status concerns of Hauksbee's age. During the eighteenth century the rise of the science lecturer and of public science rendered those concerns increasingly archaic and irrelevant in England. Many modern historians miss them completely.

In Desmarest's Paris of the 1750s, where middle-class ferment against the ancien régime was gathering pace, society was in important ways similar to Hauksbee's own. But the French academicians read Hauksbee's work in ignorance of the social circumstances of its production. Distanced from these, Desmarest could present Hauksbee as an exemplary natural philosopher. But the academicians who promoted the image were either naïve or disingenuous. Desmarest was not prepared to believe that M. Hauksbee physicien could 'abuse [his] trust by turning [his] machines into commercial objects'. ${ }^{106}$ Yet that is precisely what Hauksbee and his fellow science lecturers did, and how, in Sprat's phrase, he chiefly laboured for present livelihood. Had Desmarest known about the ignoble nature of the work Hauksbee did, he would surely have treated him no better than did the Royal Society. Hauksbee was a classy experimenter, but other considerations of class mattered more.

104 Desaguliers, op. cit. (16), Preface, p. $c^{v}$.

105 Hauksbee, op. cit. (26), Dedicatory letter (to John, Lord Somers), my emphasis.

106 Desmarest, op. cit. (27). 